
the conditions of the Creative Commons Attribution-NonCommercial-ShareAlike licence <http://creativecommons.org/licenses/by-nc-sa/3.o/ > . The written permission of Cambridge University Press must be obtained for commercial re-use.

doi:10.1017/So144686X12001377

\title{
Home-making of older Antillean migrants in the Netherlands
}

\author{
LOUISE MEIJERING* and DEBBIE LAGER $\dagger$
}

\begin{abstract}
A group of 141,345 immigrants from the Netherlands Antilles, a former colony, live in the Netherlands. An increasing number of these migrants are at or above retirement age, and for them, the question of where they want to grow old becomes relevant. It is important for people to age in a place where they feel at home, as attachment to place increases wellbeing in old age. In this article we discuss how older Antillean migrants in the Netherlands make their house and immediate living environment into a home. We focus on home-making practices in a broader cultural context, and in relation to wellbeing. These topics are addressed by drawing on qualitative life-history interviews with Antillean older people, who live in a co-housing community for older adults. It turns out that objects which remind the participants of their home country play an important role in making a home. Also, the community, with people from similar backgrounds, contributes to a sense of home. Finally, the presence of children and other family members is a key motivation for the participants' decision to age in the Netherlands.
\end{abstract}

KEY WORDS-home-making, wellbeing, Antillean migrants, The Netherlands, qualitative methods.

\section{Introduction}

The Netherlands Antilles are a group of islands in the Caribbean, consisting of the islands of Aruba, Bonaire, and Curaçao off the Venezuelan coast, and Saba, Saint Eustatius, and Saint Martin south-east of the Virgin Islands (see Figure 1). The Antilles are former colonies of the Netherlands, and part of the Kingdom of the Netherlands. ${ }^{1}$ People can migrate relatively easily between the Antilles and the Netherlands, especially since Antilleans have

* Population Research Centre (PRC), Urban and Regional Studies Institute (URSI), Faculty of Spatial Sciences, University of Groningen, The Netherlands.

$\dagger$ Cultural Geography Department, Urban and Regional Studies Institute (URSI), Faculty of Spatial Sciences, University of Groningen, The Netherlands. 


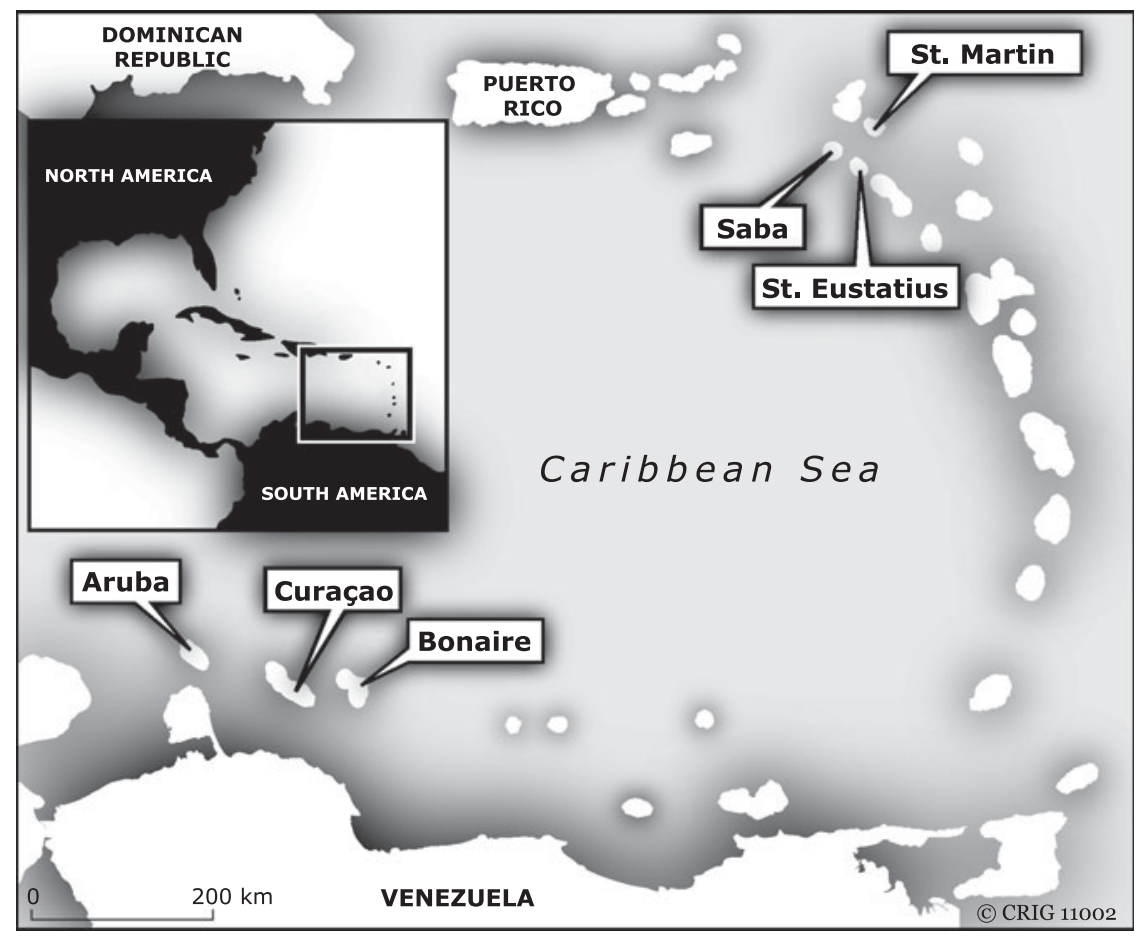

Figure 1. The location of the Dutch Antilles.

Dutch nationality (Sharpe 2005). On 1 January 201 1, 141,345 Antilleans were living in the Netherlands, 5,345 of whom were aged 65 years and above (Centraal Bureau voor de Statistiek 2012).

Since the 1960s, many Antilleans have come to the Netherlands to increase their life opportunities, and those of their children, through better employment, education and welfare (Merz et al. 2009). Because of the colonial history, immigrants from the Netherlands Antilles are usually familiar with the Dutch language and culture before they arrive (Merz et al. 2009; Zorlu and Hartog 2002). However, as a group, they hold a marginal position in Dutch society, with relatively high unemployment rates, and low incomes (Grosfoguel 1997; Snel, Engbersen and Leerkes 2006). This applies to both the group as a whole, and to Antilleans aged 55 years and older (Schellingerhout 2004).

In this article we explore the relationships between home-making and wellbeing of older Antillean migrants in the Netherlands. Central questions are: (a) how do older Antillean migrants make a home in the Netherlands? (b) How does attachment to the home place affect the experienced wellbeing of older Antillean migrants? 


\section{Home-making, ageing, wellbeing and migration}

Older adults and their relations with place have been studied in the field of geographical gerontology since the 1970s. According to Andrews et al. (2007), geographical gerontology is concerned with a variety of spatial scales, both at individual and population level, encompassing health and health care in relation to place, as well as older adults' social and cultural lives. One specific area of study is the micro-scale, which encompasses, for instance, the home (Andrews et al. 2009).

\section{Making a home in old age}

When studying how people are 'in place', Rowles (1983) has identified three elements in the connection between people and their environment: (a) physical insidedness, which refers to the behavioural rituals that we develop in places; (b) social insidedness, which means the social meaning of a place, constituted through interaction with others; and (c) autobiographical insidedness, which refers to the meaning places obtain because significant life events take place there. In a later work, Rowles and Watkins (2003) discussed the 'hearth' or home as a place of centring, a place of safety and security, where abstract space is turned into meaningful place. The home is inscribed with the identities of its inhabitants, which are often recognised through its location, exterior, interior design, furniture and decoration (Dayaratne and Kellett 2008). It is continuously created, adapted and modified. In the ongoing process of (re)creating a home place, people build connections to a significant place, ground their personal experiences and embed their personal identities within it.

Feeling at home is said to have a positive effect on the wellbeing of older adults (Rioux 2005; Rubinstein and Parmelee 1992; Wiles et al. 2009). Through feeling connected to their home, they experience a sense of autonomy, control over their everyday lives, increased self-confidence and social integration (Smith 2009). Cutchin (2005) argues that since the home plays a significant role in constituting older adults' wellbeing, it is important to look at different aspects of home-making, both positive and negative. Older adults typically spend much time at home, as decreasing physical mobility makes it less easy to venture outside (Andrews and Phillips 2005; Rioux 2005; Rubinstein and Parmelee 1992; Smith 2009; Wiles et al. 2009). As such, it can become both a place of refuge, and a place in which people feel locked up against their will.

As older adults are likely to spend more time at home, the objects present in their homes become more important for them. People personalise their homes through decorating it with a variety of significant objects/possessions 
such as paintings, musical instruments, cupboards, rugs, clocks, jewellery and photographs (see also Rowles and Watkins, 2003). In the context of this article we focus on the emotional attachment of older adults to the personal possessions they keep in their home, regardless of any material value. Older adults tend to value objects increasingly for the memories and relationships to other people they represent, rather than for their material value (Belk 1992).

In the literature on home-making, place attachment and possessions, a distinction is made between the symbolic meaning of the relation with other people, and the symbolic meaning of the relation with specific places and cultures (Belk 1992). ${ }^{2}$ Both meanings may be represented through the same object. Objects that are most commonly associated with other people are, for instance, photographs, received gifts and/or heirlooms (Shenk, Kuwahara and Zablotsky 2004). Such possessions represent (part of) personal networks and evoke feelings of being loved and cared about. The objects can be seen as extensions of a person and add to the making of the home as a social place (Rubinstein and Parmelee 1992). Even though they may be far away in real life, significant others can still be 'with' a person through their representation in a photograph or memento (Rechavi 2009). Meaningful places are most often visually represented through objects such as paintings or photographs (see Tolia-Kelly 2004).

In later life, significant objects in the home provide a sense of stability through their continuous presence in the home place (Belk 1992). Objects being moved or removed may be experienced as disruptive. Similarly, changes to the exterior of the house, or to its immediate environment, may result in feelings of disorientation (Rowles and Watkins, 2003).

\section{Culturally embedded homes of migrants}

It has been argued that people in all cultures are committed to homemaking, or creating a place where they can be themselves (Dayaratne and Kellett 2008). However, home-making is a cultural process, which means that culturally defined rules for what a home should look like exist. Individuals equate these rules against their personal preferences regarding room function, furniture, decoration and objects, thus creating homes that are distinctly individual but culturally embedded (Rubinstein and Parmelee 1992). The cultural embeddedness of home-making makes the process especially interesting in the context of migration. Migrants who belong to two (or more) cultures may choose elements from each in the process of home-making (Belk 1992).

For migrants, being aware of and understanding their host society is important in being able to make a home there. Command of the local 
language is a key factor in becoming at home in a place (Drozdzewski 2007; Meijering and van Hoven 2003). Not being able to communicate effectively with other people or not being able to understand official information is detrimental in any society, and may negatively influence wellbeing. Ip, Lui and Chui (2007) described the poor English-language skills of older Chinese immigrants in Australia as a direct cause of their social isolation. Also, social conventions about how to interact with other people differ between societies. Migrant older adults may stick to familiar ways of trying to establish social contacts, which may be misunderstood by the host population. Becker (2003) stressed that understanding the complexity and wealth of social relationships of older migrants is vital in order to be able to understand what keeps them in place.

Many (older) migrants are part of transnational families, in which part of the family lives in the home country, and another part has migrated. People who live in transnational families support each other, for instance through care-giving, but also through 'distant thinking' (Baldassar 2007). Older migrants typically feel connected to family members in both home and host country, and live 'linked lives' with their kin in both locations (Treas 2008). Such construction of one's life in relation to that of significant others is grounded in cultural constructions of ageing and caring. In transnational lives that are experienced to be closely linked to those of family members, giving and receiving transnational support, or the lack of it, can evoke complex emotions, such as guilt, obligation, longing and homesickness (Baldassar 2007).

\section{Methodology}

The main aim of this article is to discuss how older Antillean migrants in the Netherlands make their house and immediate living environment into a home, while focusing on home-making practices in a broader cultural context, and in relation to wellbeing. ${ }^{3}$ To achieve this, we adopted a qualitative approach, and interviewed people who resided in a co-housing community for Antillean, Aruban and Surinam older adults, who had come from Aruba and Curaçao, the largest islands of the Antilles. Eight migrants aged between $6_{5}$ and 85 were interviewed in March and April 2010. The community was established in 2003, and is located in a town in the north of the Netherlands. The community consists of a number of (rental) apartments, located on different floors of a larger building. One apartment serves as a 'common room' for the members, where they get together for coffee and lunch once a week. The other apartments in the building are inhabited by older adults and disabled people. 
TAB LE 1. Characteristics of the participants

\begin{tabular}{|c|c|c|c|c|c|}
\hline Name & Gender & Age & Marital status & $\begin{array}{l}\text { Reason for move } \\
\text { to Netherlands }\end{array}$ & $\begin{array}{l}\text { Years spent in } \\
\text { the Netherlands }\end{array}$ \\
\hline Teagle & Male & $65^{-70}$ & Married & Economic prospects & $20-30$ \\
\hline Jennifer & Female & $65-70$ & Married & Joining partner & $20-30$ \\
\hline Kiyana & Female & $70-75$ & Single/divorced & $\begin{array}{l}\text { Education/economic } \\
\text { prospects }\end{array}$ & $4^{\mathrm{O}-5^{\mathrm{O}}}$ \\
\hline Margriet & Female & $65^{-70}$ & Married & $\begin{array}{l}\text { Joining partner/ } \\
\text { children's education }\end{array}$ & $3^{0}-4^{0}$ \\
\hline Melvin & Male & $7^{0}-75$ & Single/divorced & Economic prospects & $20-30$ \\
\hline Omaira & Female & $7^{0}-75$ & Single/divorced & Joining children & $5^{-10}$ \\
\hline Joanie & Female & $80-85$ & Single/divorced & $\begin{array}{l}\text { Education/joining } \\
\text { sibling }\end{array}$ & $20-30$ \\
\hline Shudeska & Female & $5^{0-}-55^{2}$ & Single/divorced & Joining children & ${ }^{0}-5$ \\
\hline
\end{tabular}

Notes: 1. For issues of confidentiality, the actual number of years spent residing in the Netherlands cannot be provided.

2. Shudeska was not yet $6_{5}$, but she was a member of the co-housing community and her views were relevant: she had gone through processes of migration and home-making similar to the other community members.

Most older migrants in the Netherlands live independently, rather than in a co-housing community (Aedes-Actiz Kenniscentrum Wonen-Zorg 2012). However, we chose to study a co-housing community, since we wanted to understand the role of a shared cultural background in migrant homemaking. The studied community is the first co-housing community for older migrants in the northern Netherlands. 4 In the interviews, we discussed how the participants' wellbeing was affected by living together with people with a similar cultural background.

At the time of the interviews, 11 people were living in the community and all but one of our participants resided in it. Margriet ${ }^{5}$ (see Table 1) did not live in the community, but she was a regular visitor, participated in the common activities and identified as a community member. In the interviews, we asked the participants to tell their life-histories, and probed with regard to home-making and self-reported wellbeing. For instance, we asked what the participants had done to make themselves at home in the residential community; what belongings they had taken with them and why they had taken these, what strategies they employed for getting to know other people; which people were important for them, and why. We chose to adopt a qualitative approach, to gain deep insight into the experiences of the participants themselves (Gabriel and Bowling 2005).

Access to the community was gained by the second author, who established contact with its founding member and current co-ordinator. The coordinator invited her to a social community meeting, in which she introduced herself, explained details of the research and asked for 


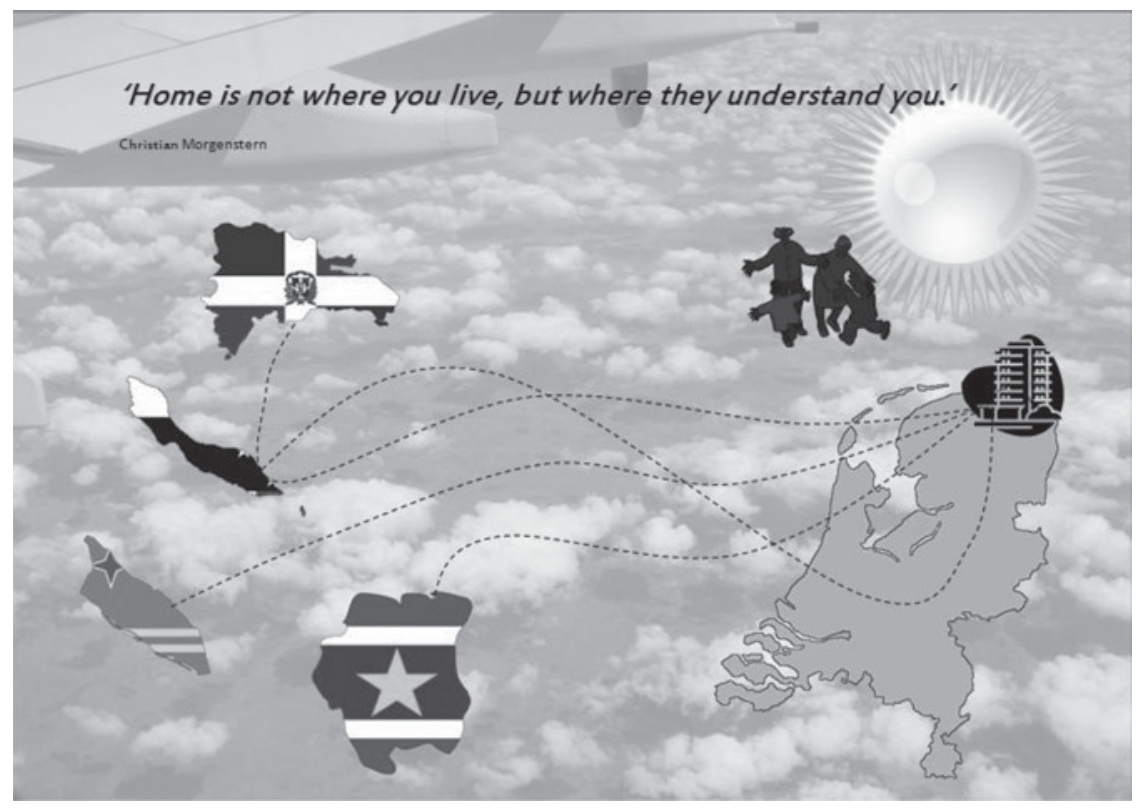

Figure 2. Poster through which the results were presented to the community.

collaboration. One interview was carried out by the first author, the rest by the second author. The participants and some of their characteristics are recorded in Table 1.

The interviews were recorded, transcribed and analysed with help of QSR NVivo, a software package for qualitative data analysis. Both authors first read all the interviews and created a common coding system. Then, both authors coded all the interviews with the general codes and discussed the results. Subsequently, the first author continued to analyse the data in more detail. Together, we presented the first results of the study to the community, in the form of a poster which was made by the second author (see Figure 2). Both the participants and the community members who did not participate in the project enjoyed the meeting, and recognised themselves in the reported results. Together, they decided to put the poster on the wall of the common room. This shows that we built rapport with all community members, and that the results represent the community as a whole.

The current study is small in scope, and provides in-depth insight into the ageing experiences of older migrants. Although the discussed experiences are individual stories, they serve to draw out more general processes that are relevant in the context of ageing migrants, such as the longing for the home country, and the ties with children and other family members. 
At our institute, there was no formal procedure to review the ethical issues at stake in studies such as this one. Participation in any interview was voluntary, with each person reassured of confidentiality. In the context of research ethics, we find it important to discuss the many differences between the researchers (female, aged 25 and 30 at the time of the fieldwork, and Dutch) and the participants. Although we attempted to conduct the study without harm for the participants, the interviews may have affected the participants' self-consciousness and confidence to some extent, in particular with regard to language. The interviews were carried out in Dutch, the second language of the participants. As 'languages are highly metaphorical, mythical, poetic and full of hidden meanings, riddles, and assumptions' (O'Leary 2009: 33), the sometimes limited command of the Dutch language of the participants may have resulted in loss of meaning or misinterpretation by the researchers. Being confronted with interviewers who were fluent in Dutch seemed to make some participants feel self-conscious and insecure about their language skills. In addition, we had to get used to the accents and grammatical preferences of the participants. When transcribing the interviews, some expressions or phrases could not be understood, and were left out of the analysis. In the next section, language is discussed in more detail as a cultural difference between the Antilles and the Netherlands.

\section{Making a home in the Netherlands}

In this section we describe how Antillean migrants attempt to make a home in the Dutch culture. Two cultural differences that were discussed in the theoretical framework on migrant home-making had a particular effect on the sense of home and wellbeing of the participants: language and social structure.

\section{Language}

The first language of most of the participants is Papiamentu, a Creole language based on Portuguese and influenced by Spanish (Britannica 2009). They learned Dutch in primary and high school. Most participants said that having learnt Dutch back home had enhanced their integration in the Netherlands. However, the Dutch they had learned in school turned out to be different from the Dutch spoken in the Netherlands, which has been argued by Sharpe (2005) and is exemplified by the following quote:

She said to me: woman, don't howl. And you know, howling you have heard, you've learned it in school, dogs howl. And then I said between my tears: I don't howl, I cry! That's the way I became acquainted with Dutch dialects. (Joanie) 
Most participants experienced similar communication problems upon their arrival in the Netherlands. Some learned to speak Dutch fluently, which facilitated their integration into Dutch society. However, others had difficulties learning Dutch, and continued to struggle with it over time. They were constantly aware of their inability to speak as fluently as a native speaker:

But you can also sense it when someone [says] something fluidly in a language. You listen how I pronounce the word, you listen how I pronounce the word. You don't see insecurity. (Teagle) ${ }^{6}$

As the participants were unable to master the language, they experienced an ongoing feeling of insecurity when speaking Dutch. This prevented some participants from feeling 'at home' in the Netherlands. Similar results have been reported in other studies on migrant experiences (Drozdzewski 2007; Meijering and van Hoven 2003).

\section{Social structures: warm and cold people}

The participants indicated that they value being part of the social group of Antilleans, because they feel known and loved among them. Kiyana expressed this as follows:

When I am [on Curaçao], I enjoy it that the people are so warm, so cordial and warm.... The people are like a warm blanket around you. I always enjoy it.... And upon coming back, I miss the warmth, the cordiality of the people. (Kiyana)

The warmth of people as described here can be related to notions of individualism and collectivism as identified by Geert Hofstede (2001) in his work on dimensions of culture. Generally, it has been found that Antillean immigrants have more collectivistic and family-oriented values than the Dutch, who cherish individual autonomy (Merz et al. 2009). As a result of these differences, it was difficult for some of the participants to build up social contacts with the Dutch:

Our culture is very different. For example, when I hear an ambulance, and it stops here and collects someone over there, I would check who it is, and I would ask her husband or wife how he or she is. But here, they don't appreciate that. There used to live a couple over there, I used to greet them when I saw them. And then he fell ill, and was admitted to the hospital. I asked her how he was, and I asked another neighbour. And one day, the neighbour said that he had passed away, so I went to see her. And she did not appreciate it, but asked me what I was coming to take from her. (Margriet)

Margriet subsequently told us that her lack of social relationships with her neighbours and other Dutch people exerted a negative influence on her wellbeing:

So, and then you start to think, you will never become one [with the Dutch]. You will remain a foreigner, a stranger. (Margriet) 
She related her failures to establish contact to the self-centredness of the Dutch people she met. Similar experiences were described by other participants. Those participants who had been staying in the Netherlands for a longer period of time generally felt that the individualist nature of Dutch society had intensified over the years. When they arrived in the 1960 s or 1970 s, the Dutch people were experienced as more friendly, concerned with others, and welcoming to newcomers. These experiences can be situated in the context of post-colonial migration. Sharpe (2005) has argued that the first small group of post-colonial migrants in the 1960 s and early 1970 os consisted of elite, culturally assimilated students, who have integrated well into Dutch society. However, later migrants typically found it more difficult to make a home in the Netherlands, which is related to, for instance, strict policies with regard to integration, and no recognition of cultural rights of post-colonial citizens (Sharpe 2005).

The participants often spoke about how they missed the warmth of the Antillean climate and people. We found that in spite of this, they developed ingenious ways to make their home in the Netherlands, which we discuss in the next section.

\section{Giving meaning to the house}

\section{Significant objects}

Most participants stressed that they came to the Netherlands with only a suitcase filled with clothes, and few memorabilia. Those who came to the Netherlands during the 1960 os and 197 os were dependent on relatives back home to send them the typically Antillean products that they missed, such as food, jewellery, religious items and hair care products:

I: You told me that you often received packages from Curaçao. What was usually in those?

J: Well, good stuff. There are certain delicacies made there, of which my mum thought, [I'll send them to Joanie]. Delicacies that I couldn't get in the Netherlands, that [she knew] I longed for.... Cans with good food, or plantain [type of banana].... Sent with love. (Joanie)

Another participant told us about the special hair products that her mother sent her. The received products not only reminded the participants of their home place, but also of the people at home, who sent them their favourite products as a symbol of their love. Our participants lived in transnational families between the Netherlands and the Antilles (see also Lunt 2009), and experience their lives as linked with those of other family members. Important decisions, such as migration, are supported by other 
family members, and seen as relational achievements (see Hörschelmann $2011)$.

A sense of home can be created through decorating it with significant objects, which are markers of favourite places and people. The participants decorated their personal homes in the Netherlands with pictures and paintings depicting places on the Antilles. These images serve to remind them both of the Antillean landscape in general, and of personal experiences 'back home'. For instance, one of the participants showed us the picture of a bridge on Curaçao in her living room, and shared the meaning it has for her:

And this is the Emma-bridge on Curaçao, the famous pontoon bridge. You can't find a bridge like that anywhere else in the world. And it is still there, the traffic can't cross it anymore, it has become a footbridge.... I lived on this side, this side of the bridge.... I have walked a lot over the bridge, and I have driven my car over it. In the past, you could cross it by car. (Kiyana)

The bridge is a significant place on Curaçao for Kiyana, a source of pride about her roots. She had to cross the bridge by car for her work as a nurse, but had difficulties with driving its slope. As a result, she got stuck on the bridge several times, and her husband forbade her to continue using the car. However, she practised with her brother until she got better at driving, and managed to keep her job and independence. The picture of the bridge evoked these complex memories with her, and can be seen as a symbol of her pride about her home island, as well as of her status as an independent woman.

All participants had pictures in their living rooms of family members, such as (grand)children. The photographs act as guides through the participants' memories, and help them to connect with the represented people:

When I am with my family, with my children, you see, there they all are, I love that (she points to the pictures). All my grandchildren. That makes me feel happy. (Omaira)

She talks about her children and grandchildren as if she is literally with them when looking at their pictures. This illustrates the importance of family relationships for the participants, as will be discussed in the next section.

\section{Home-making through people}

For the participants in this study, home-making turned out to be something highly defined by the presence of significant others, especially their children:

So my son went to the Netherlands, to get a good education, yes? And two years after my son, my daughter also went. So at that moment, I was alone on Curaçao. That situation was not good for me, my family consists of three persons, my daughter, my 
son and I, and at that moment both children lived in the Netherlands... Yes of course, of course, I miss Curaçao a lot, a lot. But my children live here, that is very important. (Shudeska)

M: I cannot live that far away from my children ... a 19-hour flight, no.

I: Where your children live...

M: That's where I want to be. I do want to go [back to Curaçao], but I cannot take them all with me, I can't. So I'll just stay here. (Margriet)

Both Shudeska and Margriet said they stay in the Netherlands because of their children, which has also been found in more applied research on the social networks of older Antilleans in the Netherlands (Meulenkamp et al. 2010; Schellingerhout 2004). In the gerontology literature on migration experiences, the role of transnational families in the migration process has also been stressed (Blakemore 1999; Lunt 20o9; Treas 2008). The cited studies resonate a more generally reported positive association between older adults' wellbeing and living close to significant others (Davidson, Warren and Maynard 2005; McKevitt et al. 2005; Peace, Holland and Kellaher 2005). Based on the literature, we assume that relations with family members were less important for our participants in earlier stages of their lives, although we did not address this explicitly in the interviews.

On the Antilles, it is common for older adults to live with their adult children, whereas in the Netherlands, older adults generally prefer to continue to live independently for as long as possible, before moving to an institution. Our participants, however, did not express a wish to live in extended families; they seemed to have internalised the Dutch ideas that family members are independent from each other. Blakemore (1999) similarly described that African-Caribbeans in the United Kingdom prefer to live in family arrangements that resemble those of the native British population.

Although our participants wanted to live close to their children, they did not want to live together with them. They rather shared the Antillean social and cultural values within their peer group of older Antilleans in the Netherlands. It is possible that the participants chose to live in a co-housing community for older migrants because it facilitates their independence, and functions as a 'surrogate family' at the same time. It may be that older Antilleans who do not live in a co-housing community would prefer to live in extended families, but that was outside the scope of this study.

For social interaction with people their own age, the participants enjoy interacting with people from a similar cultural background, both inside and outside the co-housing community. This confirms findings by Schellingerhout (2004) and Meulenkamp et al. (2010), who found that social contacts within one's own cultural group enhance the quality of life of 
older Antilleans in the Netherlands. The participants have built up a social network consisting of Antilleans over the years, but indicated that reliving the past and sharing memories of the Antilles had become more important for them over time:

M: I go back to my roots. Together, we dig up stories about people, my children will have heard those stories from me, but they did not share the experiences.

I: Of. ..?

M: The Antilles, the old days. For instance, when I say, do you remember these long sticks, blue and beige? That was soap to wash your clothes. But it was sold in pieces, so you could buy half of it, or a smaller part. My children will not, they cannot remember what such a thing looked like. And we had scales to weigh everything. A pound of sugar, a pound, everything was packed into bags. And some things like peanuts, they were not weighed. You would have a special box, when you fill it up, it costs that much. The children were not raised with that, so. With people your own age, you can just chat about such crazy things. (Margriet)

Through contacts with their peers, the participants relive life on the Antilles, and return to the home of their youth. However, when they return to the Antilles for holidays, they miss their 'own' lives in the Netherlands: they miss their home.

\section{Conclusions}

In our small-scale study on home-making and wellbeing of older Antillean migrants in the Netherlands, participants described moving to the Netherlands for a variety of reasons and at various stages of their lives: to study, work, live with a spouse, (grand)children or siblings. It turned out that for all of them, decorating the home with significant objects was important in home-making. Paintings and photographs reminiscent of specific places on the Antilles, as well as photographs of family members such as ancestors, children and grandchildren, evoked strong feelings of home and belonging. Also, the participants felt at home in the Netherlands in terms of social networks consisting of (grand)children, siblings and fellow Antilleans. They constructed their lives and experienced wellbeing as linked to those of significant others, and see, for instance, their migration as a relational achievement (Hörschelmann 2011 ). Typically, in their old age, they depend on children or siblings who live nearby for emotional and practical care, and we found that the wellbeing of older migrants is likely to be higher when their children and siblings live close to them. However, in practice, the children and siblings of most participants lived both in the Netherlands and on the Antilles, which meant that the participants effectively continued to live in 
transnational families. In addition, although family often plays an important role in migration, it is important to acknowledge the personal and diverse nature of migration motivations and experiences, as has been argued by Baldassar (2007). While making a home in the Netherlands, the participants derive an important part of their wellbeing from connecting with the Antilles, their place of origin. In other contexts, similar findings have been reported, for instance by Bolzman, Fibbi and Vial (2006), who studied older Italian and Spanish migrants in Switzerland. Thus, living between cultures provides a risk for older adults, as it can have a negative effect on their quality of life and wellbeing (Peace, Holland and Kellaher 2005). Although this probably applies to migrants at all ages, we argue that it is particularly relevant for older migrants, because older adults typically increasingly depend on other people, and may not be able to choose how to shape their own life between two cultures anymore. Our participants actively chose to live a community life, in connection with their roots. In other words, they were able to age 'in place' ( $\mathrm{see}$ Wiles et al. 2012), which contributed positively to their wellbeing. Our participants engaged in 'creating meaning through place-centred activity' (Cutchin 2003: 1084), for instance through drinking coffee together, and talking about the Antilles. Life outside their community would make it more difficult for the participants to remain in touch with their Antillean roots, thus negatively affecting their wellbeing.

In this article, we attempted to contribute to geographical gerontology by discussing the complex relations between older migrants' identities, home-making and their experiences of ageing. As the current study is of limited scope, it would be interesting to further explore the cultural dimension of older adults home-making. In addition, it could be interesting to study (migrant) co-housing communities as 'landscapes of care' (Milligan and Wiles 2010), by observing how older adults are cared for in these communities, by whom, and how care influences their wellbeing. Furthermore, the more general theoretical discussion on attachment to places (Lewicka 2011; Scannell and Gifford 2010) in relation to old age seems worthwhile to be further explored within geographical gerontology.

\section{Acknowledgements}

We would like to thank Tamara Kaspers of the Groningen Centre for Spatial Information (CRIG) for her cartographical work. Furthermore, we are grateful for the constructive comments of the editor and three anonymous referees, which were of great help in improving the article. 


\section{NOTES}

1 Aruba, Curaçao and Saint Martin have a 'status aparte' within the Kingdom of the Netherlands. This means that they function as separate countries and have a high degree of independence. Aruba obtained 'status aparte' in 1986, the other two islands more recently in October 2010. The other three islands, Bonaire, Saint Eustatius and Saba became special Dutch municipalities in October 2010, and fall under Dutch law.

2 Rowles (1983) makes a similar distinction between social and autobiographical insidedness in his discussion on the relations between people and place, to which we referred above.

3 In another article based on this study, by Lager, van Hoven and Meijering (2012), we focus on place attachment and wellbeing that older Antillean migrants experience in the co-housing community and neighbourhood.

4 In the Netherlands, migrant co-housing communities are increasing in popularity. Approximately $5^{\circ}$ of the $55^{\circ}$ co-housing communities for older adults are targeted at or constituted by migrants (Aedes-Actiz Kenniscentrum Wonen-Zorg 2012).

5 All names used are pseudonyms to ensure confidentiality.

6 The part in italics was spoken in English by the participant.

\section{References}

Aedes-Actiz Kenniscentrum Wonen-Zorg 2012. Gemeenschappelijk wonen voor oudere migranten [Communal Living for Older Migrants]. Available online at http:// www.kcwz.nl/dossiers/kleurrijk_wzw/gemeenschappelijk_wonen_voor_oudere_ migranten [Accessed 22 May 2012].

Andrews, G.J., Cutchin, M., McCracken, K., Phillips, D. R. and Wiles, J. 2007. Geographical gerontology: the constitution of a discipline. Social Science and Medicine, 65, 1, 151-68.

Andrews, G.J., Milligan, C., Phillips, D. R. and Skinner, M. W. 2009. Geographical gerontology: mapping a disciplinary intersection. Geography Compass, 3, 5, $1641-59$.

Andrews, G.J. and Phillips, D. R. 2005. Geographical studies in ageing. In Andrews, G.J. and Phillips, D. R. (eds), Ageing and Place. Perspectives, Policy, Practice. Routledge, London, 7-12.

Baldassar, L. 2007. Transnational families and aged care: the mobility of care and the migrancy of ageing. Journal of Ethnic and Migration Studies, 33, 2, 275-97.

Becker, G. 2003. Meanings of place and displacement in three groups of older immigrants. Journal of Aging Studies, 17, 2, $129-49$.

Belk, R. W. 1992. Attachment to possessions. In Altman, I. and Low, S. M. (eds), Place Attachment. Plenum Press, New York, 37-62.

Blakemore, K. 1999. International migration in later life: social care and policy implications. Ageing $\mathcal{E}$ Society, 19, 6, 761-74.

Bolzman, C., Fibbi, R. and Vial, M. 20o6. What to do after retirement? Elderly migrants and the question of return. Journal of Ethnic and Migration Studies, 32, 8, 1359-75.

Britannica 2009. Encyclopedia Britannica. Papiamentu. Available online at http:// www.britannica.com/EBchecked/topic/442065/Papiamentu [Accessed 22 May 2012]. 


\section{Louise Meijering and Debbie Lager}

Centraal Bureau voor de Statistiek 201 2. Statline. Centraal Bureau voor de Statistiek, The Hague/Heerlen.

Cutchin, M. P. 2003. The process of mediated aging-in-place: a theoretically and empirically based model. Social Science and Medicine, 57, 6, 1077-9o.

Cutchin, M. P. 2005. Spaces for inquiry into the role of place for older people's care. International Journal of Older People Nursing, 14, 8b, $121-9$.

Davidson, K., Warren, L. and Maynard, M. 2005. Social involvement. Aspects of gender and ethnicity. In Walker, A. (ed.), Understanding Quality of Life in Old Age. Open University Press, Maidenhead, UK, 84-99.

Dayaratne, R. and Kellett, P. 2008. Housing and home-making in low-income urban settlements: Sri Lanka and Colombia. Journal of Housing and the Built Environment, 23, 1, 53-70.

Drozdzewski, D. 2007. A place called 'Bielany': negotiating a diasporic Polish place in Sydney. Social Ẽ Cultural Geography, 8, 6, 853-68.

Gabriel, Z. and Bowling, A. 2005 Quality of life from the perspectives of older people. Ageing Eं Society, 24, 5, 675-691.

Grosfoguel, R. 1997. Colonial Caribbean migrations to France, the Netherlands, Great Britain and the United States. Ethnic and Racial Studies, 2o, 3, 594-612.

Hofstede, G. 2001. Culture's Consequences. Comparing Values, Behaviors, Institutions and Organizations Across Nations. Second edition, Sage, Thousand Oaks, California.

Hörschelmann, K. 2011 . Theorising life transitions: geographical perspectives. Area, 43, $4,378-83$.

Ip, D., Lui, C. W. and Chui, W. H. 2007. Veiled entrapment: a study of social isolation of older Chinese migrants in Brisbane, Queensland. Ageing E् Society, 27, 5 , 719-38.

Lager, D., van Hoven, B. and Meijering, L. 2012 . Places that matter: place attachment and wellbeing of older Antillean migrants in the Netherlands. European Spatial Research and Policy, 19, 1, 81-94.

Lewicka, M. 2011. Place attachment: how far have we come in the last 40 years? Journal of Environmental Psychology, 31, 3, 207-30.

Lunt, N. 20o9. Older people within transnational families: the social policy implications. International Journal of Social Relations, 18, 3, 243-51.

McKevitt, C., Baldock, J., Hadlow, J., Moriarty, J. and Butt, J. 2005. Identity, meaning and social support. In Walker, A. (ed.), Understanding Quality of Life in Old Age. Open University Press, Maidenhead, UK, $130-45$.

Meijering, L. and van Hoven, B. 2003. Imagining difference. The experiences of 'transient' Indian IT-professionals in Germany. Area, 35, 2, 1 74-82.

Merz, E., Özeke-Kocabas, E., Oort, F. J. and Schuengel, C. 20o9. Intergenerational family solidarity: value differences between immigrant groups and generations. Journal of Family Psychology, 23, 3, 291-300.

Meulenkamp, T. M., van Beek, A. P. A., Gerritsen, D. L., de Graaff, F. M. and Francke, A. L. 2010. Kwaliteit van leven bij migranten in de ouderenzorg. Een onderzoek onder Turkse, Marokkaanse, Surinaamse, Antilliaanse/Arubaanse en Chinese ouderen [Quality of Life of Migrants in Elderly Care. A Study Amongst Turkish, Moroccan, Surinam, Antillean/ Aruban and Chinese Older People]. Netherlands Institute for Research in Healthcare (NIVEL), Utrecht, The Netherlands.

Milligan, C. and Wiles, J. 201 o. Landscapes of care. Progress in Human Geography, 34, 6, $73^{6-54}$.

O'Leary, Z. 2009. The Essential Guide to Doing Your Research Project. Sage, London.

Peace, S. M., Holland, C. and Kellaher, L. 2005. Environment and Identity in Later Life. Open University Press, Maidenhead, UK. 
Rechavi, T. B. 2009. A room for living: private and public aspects in the experience of the living room. Journal of Environmental Psychology, 29, 1, 133-43.

Rioux, L. 2005. The well-being of aging people living in their own homes. Journal of Environmental Psychology, 25, 2, 231-43.

Rowles, G. D. 1983. Place and personal identity in old age: observations from Appalachia. Journal of Environmental Psychology, 3, 4, 299-313.

Rowles, G. D. and Watkins, J. F. 2003. History, habit, heart and hearth: on making spaces into places. In Warner, S. K., Wahl, H. W., Mollenkopf, H. and Oswald, F. (eds), Aging Independently. Living Arrangements and Mobility. Springer, New York, $77-96$.

Rubinstein, R. L. and Parmelee, P.A. 1992. Attachment to place and the representation of the life course by elderly. In Altman, I. and Low, S. M. (eds), Place Attachment. Plenum Press, New York, 139-63.

Scannell, L. and Gifford, R. 2010. Defining place attachment: a tripartite organizing framework. Journal of Environmental Psychology, 3o, 1, 1-10.

Schellingerhout, R. (ed.) 2004. Gezondheid en welzijn van allochtone ouderen [Health and Wellbeing of Older People Originating from Other Countries]. Sociaal en Cultureel Planbureau (SCP) Publication 2004/16, SCP, The Hague.

Sharpe, M. 2005. Globalization and migration: post-colonial Dutch Antillean and Aruban immigrant political incorporation in the Netherlands. Dialectical Anthropology, 29, 3/4, 291-314.

Shenk, D., Kuwahara, K. and Zablotsky, D. 2004. Older women's attachments to their home and possessions. Journal of Aging Studies, 18, 2, $157-69$.

Smith, A. E. 2009. Ageing in Urban Neighbourhoods. Place Attachment and Social Exclusion. Policy Press, Bristol, UK.

Snel, E., Engbersen, G. and Leerkes, A. 2006. Transnational involvement and social integration. Global Networks, 6, 3, 285-308.

Tolia-Kelly, D. P. 2004. Materializing post-colonial geographies: examining the textural landscapes of migration in the South Asian home. Geoforum, 35, 6, 675-88.

Treas, J. 2008. Transnational older adults and their families. Family Relations, 57, 4, $468-78$.

Wiles, J. L., Allen, R. E. S., Palmer, A. J., Hayman, K. J., Keeling, S. and Kerse, N. 2009. Older people and their social spaces: a study of well-being and attachment to place in Aotearoa New Zealand. Social Science E Medicine, 68, 4, 664-71.

Wiles, J. L., Leibing, A., Guberman, N., Reeve, J. and Allen, R. E. S. 2012. The meaning of 'ageing in place' to older people. The Gerontologist, 52, 3, 357-66.

Zorlu, A. and Hartog, J. 2002. Migration and immigrants: the case of the Netherlands. In Rotte, R. and Stein, P. (eds), Migration Policy and the Economy: International Experiences. Hanns Seidel Stiftung, Munich, 1 19-40.

Accepted I3 November 2012 ; first published online 2 I December $20 \mathrm{II}_{2}$

Address for correspondence:

Louise Meijering, Population Research Centre, Faculty of Spatial Sciences, University of Groningen, PO Box 800, 9700 AV Groningen, The Netherlands.

E-mail: 1.b.meijering@rug.nl 